\title{
Management of Flood Protection System of Dewa Ruci Underpass in Bali
}

\author{
P. M. Risnadinata ${ }^{1}$, I.N.S. Kumara ${ }^{2}$, and W.G. Ariastina ${ }^{3}$ \\ 1,2,3 Master of Electrical Engineering Program, Faculty of Engineering \\ Udayana University, Bali, Indonesia \\ satya.kumara@unud.ac.id
}

\begin{abstract}
Dewa Ruci intersection is one point of traffic congestion point in Bali. Dewa Ruci is a major intersection that connects the city of Denpasar, Kuta, Jimbaran, and Nusa Dua. In addressing traffic congestion, built underpass so that traffic becomes smooth when passing through the intersection Dewa Ruci. Part of the Dewa Ruci intersection is below the ground level, so risks of flooding. The source of water that potentially fills the underpass is groundwater seepage and rainfall. The flood protection of the underpass is capable of storing $1344 \mathrm{~m}^{3}$ water and with the pumping system. In this research, the maintenance, operation, and management model of the flood protection system is developed that includes the development of organizational structures and standard operating procedures to ensure that the Dewa Ruci flood protection system works well sustainably.
\end{abstract}

Keyword: underpass, management, operation, and maintenance

\section{INTRODUCTION}

Bali Island is one of the foreign and domestic tourist destinations. For some people, Bali is also the aim of seeking income and education. Such conditions, make Bali experienced overcrowding problems and the effect on the number of additional vehicles to become a major factor of congestion. Dewa Ruci is one of the lines that are often congested. Dewa Ruci intersection congestion due to a major intersection that connects between Denpasar, Kuta, Jimbaran, and Nusa Dua. According to records of Badan Pusat Statistik (BPS), the number of vehicles through the intersection of Dewa Ruci reached 74625 units per day, with a predominance of two-wheeled vehicles.

In overcoming traffic at the Dewa Ruci intersection, then Kementerian Pekerjaan Umum, through Satuan Kerja Pelaksanaan Jalan Nasional Metropolitan Denpasar (SATKER PJN), has undertaken the construction of underpasses. The underpass is a road below the other and across in one field but one segment is above or below other roads.

Generally, the underpass has the potential for flooding due to a lower position than the surrounding roads. In the area around the underpass also experienced groundwater seepage will occur that increase the likelihood of flooding. If underpasses flooded, then the vehicle will pass through the intersection Dewa Ruci should use the path of overcoming bottlenecks and solutions will be a source of congestion. Then the Dewa Ruci underpass using a flood protection system as a solution to the problem of flooding.

Flood safety system Dewa Ruci underpass designed to have a water storage space that serves as rainwater and groundwater seepage. Furthermore, water that meets the space which has been issued to the existing drainage around the Dewa Ruci intersection by using a water pump. There are eight water pumps installed on the flood protection system Dewa Ruci underpass. Two of the six water pumps operating in turns every 2 hours for 24 hours to remove the water continues to meet the water storage space. Two other pumps are used as a backup when the rising water level in the water tank if it exceeds 4 meters. The power supply is two kinds of PLN the utility company and diesel generator with a capacity of $250 \mathrm{KVA}$. Diesel generator works automatically if PLN had an interruption in electricity supply. The flood protection system that has been installed already well in operation tackling the risk of flooding in the Dewa Ruci underpass.

The flood protection system is also used in areas that have the potential for flooding such as Jakarta, Semarang, Melbourne, and some areas in the Netherlands. Potential flood in Jakarta because the land is lower than sea level. Jakarta government uses the water pump as the solution to the problem of flooding. The water pump is used as much as 
550, is installed in areas with high flood potential [14]. Previously the same system has also been applied in other countries that have a high potential for flooding, for example in the Netherlands which uses a system of polders. Polder system was developed further in the 13th century with the consummation of using windmills to pump water out of areas that are below sea level [3].

Many areas of potential flood prevention by using flood protection system and perform management operations and maintenance on the system. Operation and maintenance management is very important from a safety system functions effective and sustainable flood. The aim is that the area is not flooded.

Research by Davie who carries out the management plan of the area has great potential flooding that Port Phillip and Westernport in Victoria, Australia. In his research, Davie describes the process of development of Flood Management Plans (FMP). The FMP own development benefit flood management institutions and also for the community as well as in the region of Port Philip Westernport. The key to effective implementation of the corrective actions is continuing their discussions are needed to reduce flood risk [6].

Pieter Jong in 2007, examined the differences in policy made by the Dutch government between the water system and the water chain. Research conducted conclude their legal guarantees are not enough for the relationship between water chain and water systems, in particular for legal guarantees of cooperation between water managers and city water remains inadequate [10].

Luitzen Bijlsma in 2011, explained about water management in the Netherlands with several developments. The system used is a system that is applied to Polders on the coast and rivers. The system becomes a safety function when the water level rises. The system is also used for the protection of water in the dry season [5].

The purpose of this study was to determine the flood protection system at the Dewa Ruci underpass and make recommendations operation and maintenance management in the form of a draft organizational structure as well as standard operating procedure. The results of this study are expected to help the manager's underpass so that it can function effectively and sustainably.

\section{RESEARCH METHODS}

This research uses the observation method and the library method. An observation method in this research is data collection provided by the SATKER PJN Metropolitan Denpasar and direct observation at the Dewa Ruci underpass. This research method is shown schematically in Figure 1.

The first stage is the observation of the flood protection system, electrical system, and pumping systems Dewa Ruci underpass flooding, condition management procedures system operation and maintenance of water pumping systems, and monitoring the operation of the pump system. The second stage is to review the electrical system and pumping systems Dewa Ruci underpass flooding. The third stage is to conduct a review of operations management and maintenance of water pumping systems. The fourth stage of observation and monitoring operation of the pump system and the level of the water table. The fifth stage of data processing and analysis of the previous stage. The sixth stage of formulating and recommending standard operating procedure flood safety operation of the pump system. The seventh stage of formulating and recommending organizational structure refers to the recommendation SOP.

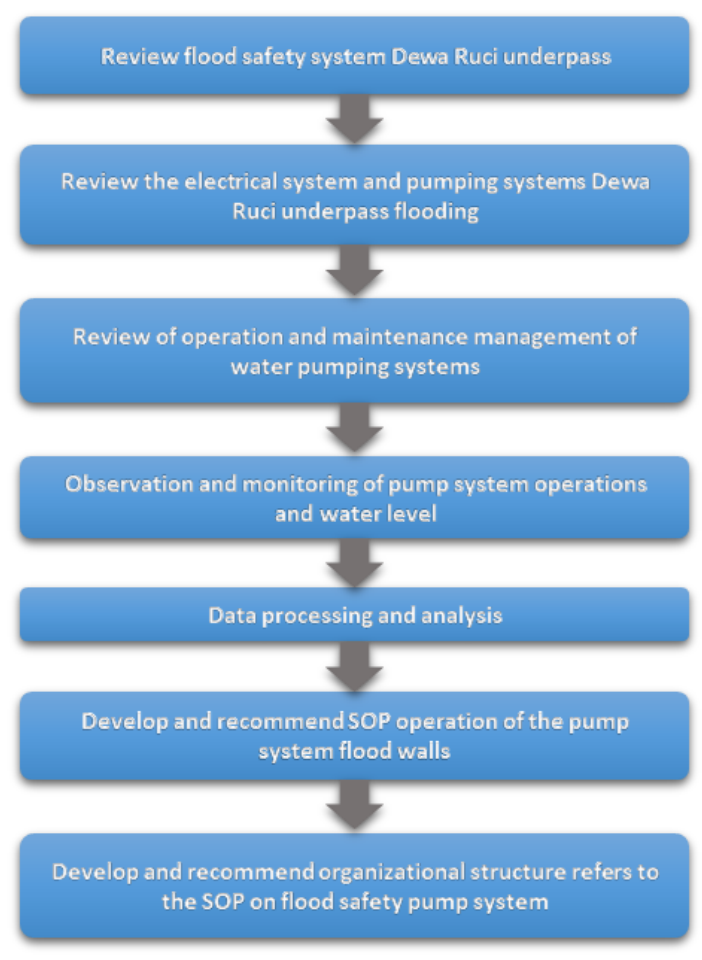

Fig 1. Schematic research methods

\section{A. Flood Protection System of Dewa Ruci Underpass}

Dewa Ruci underpass located at coordinates -8.721 south latitude and east longitude 115.1826 sculpture garden adjacent to the city called Dewa Ruci. Location underpass as shown in Figure 2.

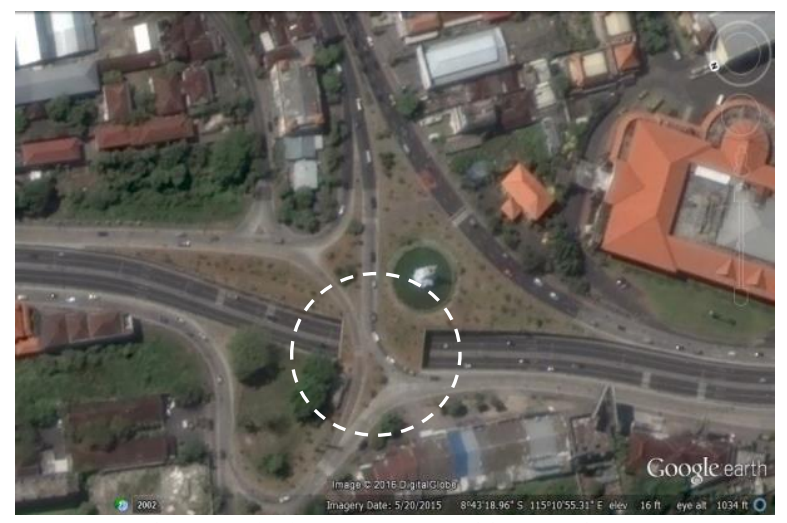

Fig 2. Looked over Dewa Ruci intersection

There are two sources of water to meet the underpass lines include rainwater and groundwater. Rainwater flowing into 
the road underpass flowed directly through the drainage located on the edge of the track and cross drain to the water tank which is located just below the lowest track of Dewa Ruci Underpass. While groundwater absorbed through capillary cracks on the walls and bottom water reservoirs accommodated therein. All the water stored inside the tank issued to the existing drainage located on the west side of the Dewa Ruci Underpass using eight pumps that work automatically water where the water flow in the river empties into the Tukad Mati river.

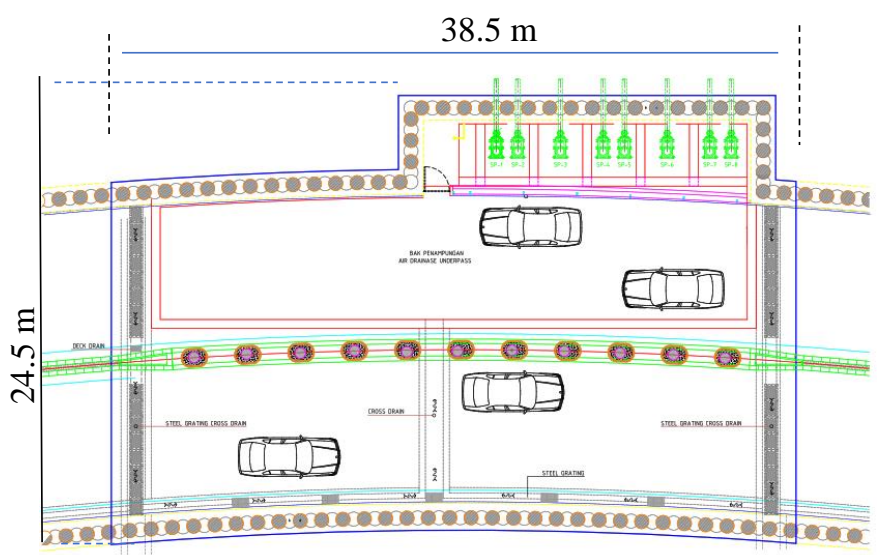

Fig 3. Looked over water reservoir Dewa Ruci underpass



Fig 4. Cross sections water reservoir Dewa Ruci underpass

Dewa Ruci's underpass has a water reservoir under the Dewa Ruci's underpass as shown in Figure 3 and Figure 4. The dimensions of the water reservoir are $1344 \mathrm{~m}^{3}$ and the volume of water that can be accommodated is $\pm 1,344,000$ liters of water.

The first water reservoir with a length of $33 \mathrm{~m}$, height $4 \mathrm{~m}$, width $8 \mathrm{~m}$, plus a second water reservoir that is the pumping chamber with a length of $18 \mathrm{~m}$, a height of $4 \mathrm{~m}$, a width of 4 $\mathrm{m}$. To ease the water reaches the water reservoirs are across drain in the middle lane Dewa Ruci underpass.

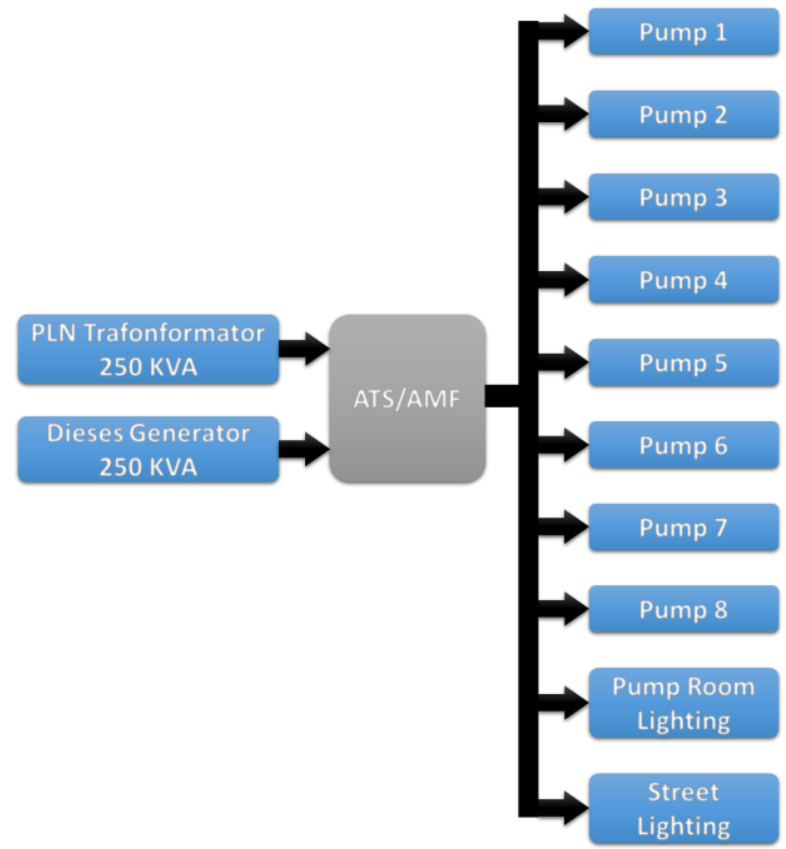

Fig 5. Schematic diagram of Dewa Ruci underpass

\section{B. Electrical System}

The main power supply used to operate the pump is sourced from the PLN supply through a transformer with a capacity of $250 \mathrm{kVA}$ as a backup used diesel generator. The diesel generator used is Stamford $400 \mathrm{~V}$, three phases, with a capacity of $250 \mathrm{kVA}$. The diesel generator works automatically in the event of a blackout from PLN using Automatic Transfer Switch (ATS) and Automatic Main Failure (AMF), which serves powering the generator if the loss of the main power supply. Schematic Dewa Ruci underpass electrical system shown in Figure 5. The pump is used submersible sewage pumps Ebara DMLEU models. The pump has a capacity of 55 to 245 gallons per minute (GPM). These pumps driven by electric motors 3-phase induction type, with the Star-Delta starting method, with the motor capacity varies between $3.7 \sim 22 \mathrm{~kW}$. The pump is mounted on a 6-inch diameter pipeline network.

\section{RESULTS AND DISCUSSION}

Conditions that fill the water elevation in the water tank Dewa Ruci underpass fluctuation. This fluctuation is caused by groundwater seepage and rainfall. Here are the results of monitoring water elevation during the study was conducted. For comparison, circumstances use water elevation level data on the condition of low intensity and high rainfall. In August the rainfall intensity is low because of no rain. Whereas December is a high rainfall intensity with a total of 74 hours of rain. All data in the table are in meters. 
TABLE I

WATER ELEVATION IN RESERVOIRS IN AUGUST 2014

\begin{tabular}{|c|c|c|c|c|c|c|c|c|c|c|c|c|}
\hline & \multicolumn{12}{|c|}{ Jam } \\
\hline & 0 & 2 & 4 & 6 & 8 & 10 & 12 & 14 & 16 & 18 & 20 & 22 \\
\hline 1 & 1,8 & 1,9 & 2,0 & 1,7 & 1,7 & 1,9 & 2,1 & 2,0 & 1,8 & 1,6 & 1,5 & 1,7 \\
\hline 2 & 1,8 & 2,0 & 1,7 & 1,6 & 2,0 & 2,1 & 1,9 & 1,6 & 1,8 & 1,9 & 1,8 & 1,9 \\
\hline 3 & 1,6 & 1,9 & 1,0 & 1,5 & 1,6 & 1,8 & 2,0 & 1,9 & 2,1 & 1,5 & 1,7 & 1,8 \\
\hline 4 & 2,0 & 1,6 & 1,0 & 1,7 & 1,7 & 1,9 & 2,1 & 2,0 & 1,8 & 1,9 & 2,1 & 1,8 \\
\hline 5 & 1,6 & 1,8 & 1,0 & 1,9 & 1,9 & 2,0 & 1,7 & 1,7 & 1,9 & 1,8 & 1,5 & 1,7 \\
\hline 6 & 1,9 & 2,1 & 2,0 & 1,7 & 1,6 & 1,7 & 1,9 & 2,1 & 1,8 & 1,5 & 1,7 & 1,6 \\
\hline 7 & 2,0 & 1,8 & 2,0 & 1,5 & 1,8 & 2,0 & 2,0 & 1,5 & 1,7 & 1,8 & 1,6 & 1,9 \\
\hline 8 & 1,9 & 2,0 & 2,1 & 1,6 & 1,7 & 1,9 & 2,1 & 1,8 & 2,0 & 1,6 & 1,5 & 1,7 \\
\hline 9 & 2,0 & 1,9 & 1,6 & 1,8 & 1,8 & 2,0 & 1,9 & 2,1 & 1,5 & 1,7 & 1,6 & 1,6 \\
\hline 10 & 1,6 & 2,0 & 1,8 & 1,1 & 1,9 & 1,9 & 1,7 & 1,8 & 1,6 & 1,7 & 1,5 & 1,8 \\
\hline 11 & 1,9 & 1,7 & 1,6 & 2,1 & 1,8 & 2,0 & 1,7 & 1,9 & 2,0 & 1,5 & 2,1 & 1,5 \\
\hline 12 & 1,8 & 2,0 & 1,9 & 1,6 & 1,5 & 1,5 & 2,1 & 1,8 & 1,6 & 1,7 & 1,9 & 2,1 \\
\hline 13 & 2,0 & 1,9 & 1,3 & 1,8 & 1,5 & 1,7 & 1,9 & 2,1 & 1,8 & 1,6 & 1,5 & 1,7 \\
\hline 14 & 1,6 & 1,7 & 1,7 & 2,0 & 1,5 & 1,8 & 2,0 & 1,9 & 1,7 & 1,7 & 2,0 & 1,8 \\
\hline 15 & 1,7 & 1,5 & 1,7 & 1,9 & 2,1 & 1,8 & 1,6 & 1,7 & 1,9 & 2,0 & 1,8 & 1,7 \\
\hline 16 & 1,7 & 1,9 & 1,9 & 1,8 & 1,9 & 2,0 & 1,7 & 1,8 & 2,0 & 1,8 & 1,6 & 1,6 \\
\hline 17 & 1,1 & 2,0 & 1,8 & 1,6 & 1,5 & 2,1 & 1,7 & 1,1 & 1,9 & 1,5 & 2,1 & 1,5 \\
\hline 18 & 2,1 & 1,5 & 1,5 & 1,7 & 1,8 & 1,7 & 1,9 & 2,1 & 1,8 & 2,0 & 1,8 & 1,6 \\
\hline 19 & 1,8 & 1,6 & 1,9 & 1,7 & 1,6 & 1,9 & 1,6 & 2,1 & 1,5 & 1,7 & 1,9 & 2,1 \\
\hline 20 & 2,0 & 2,1 & 2,0 & 1,6 & 1,9 & 2,0 & 1,8 & 1,6 & 1,7 & 1,5 & 1,8 & 1,8 \\
\hline 21 & 1,7 & 1,9 & 1,5 & 1,8 & 1,8 & 2,1 & 1,5 & 1,8 & 1,6 & 1,9 & 1,5 & 1,6 \\
\hline 22 & 2,0 & 1,8 & 1,5 & 1,5 & 1,5 & 1,7 & 1,9 & 2,1 & 2,0 & 1,5 & 1,2 & 1,9 \\
\hline 23 & 1,7 & 2,0 & 2,1 & 1,7 & 1,7 & 1,8 & 2,0 & 1,6 & 1,5 & 1,8 & 2,1 & 1,9 \\
\hline 24 & 1,8 & 1,6 & 1,6 & 1,5 & 1,9 & 2,1 & 1,8 & 2,0 & 1,7 & 1,6 & 1,8 & 2,0 \\
\hline 25 & 1,8 & 2,0 & 1,5 & 2,1 & 1,7 & 1,9 & 2,1 & 2,0 & 1,8 & 1,7 & 1,5 & 1,6 \\
\hline 26 & 1,6 & 1,7 & 1,7 & 1,8 & 1,8 & 1,6 & 1,7 & 1,9 & 1,9 & 2,1 & 2,0 & 1,8 \\
\hline 27 & 1,8 & 1,6 & 1,9 & 1,7 & 2,0 & 1,6 & 1,9 & 1,5 & 1,7 & 1,7 & 2,0 & 1,6 \\
\hline 28 & 1,6 & 1,8 & 1,7 & 2,0 & 1,5 & 1,7 & 1,9 & 2,1 & 1,8 & 1,7 & 1,7 & 2,0 \\
\hline 29 & 1,5 & 1,8 & 1,5 & 1,7 & 1,8 & 1,8 & 2,1 & 1,9 & 1,7 & 1,6 & 1,8 & 1,6 \\
\hline 30 & 1,7 & 1,9 & 1,9 & 2,1 & 2,0 & 1,7 & 1,9 & 2,1 & 1,7 & 1,5 & 1,6 & 1,8 \\
\hline 31 & 2,0 & 1,8 & 1,6 & 1,5 & 1,5 & 1,7 & 1,9 & 2,1 & 2,0 & 1,9 & 1,7 & 1,9 \\
\hline
\end{tabular}



Fig 6. Water elevation graph for water reservoirs in August 2014

August does not rainwater reservoirs, but at some time peak at $1.1 \mathrm{~m}$. The incident caused groundwater to continue to fill the water reservoir through capillary cracks. All data in the table are in meters.
TABLE II

WATER ELEVATION IN RESERVOIRS IN DECEMBER 2014

\begin{tabular}{|c|c|c|c|c|c|c|c|c|c|c|c|c|}
\hline \multirow{2}{*}{ Dte } & \multicolumn{12}{|c|}{ Jam } \\
\hline & 0 & 2 & 4 & 6 & 8 & 10 & 12 & 14 & 16 & 18 & 20 & 22 \\
\hline 1 & 1,5 & 1,7 & 1,8 & 2,1 & 1,8 & 1,7 & 1,9 & 2,1 & 2,0 & 1,8 & 1,6 & 1,7 \\
\hline 2 & 1,7 & 2,0 & 1,9 & 1,7 & 1,9 & 1,7 & 2,0 & 1,9 & 2,1 & 1,9 & 1,7 & 1,8 \\
\hline 3 & 1,1 & 2,0 & 1,1 & 1,6 & 1,7 & 1,9 & 2,1 & 1,9 & 1,6 & 1,8 & 1,7 & 1,3 \\
\hline 4 & 2,0 & 1,3 & 1,5 & 1,8 & 1,5 & 1,7 & 1,6 & 1,9 & 1,2 & 1,8 & 2,1 & 1,2 \\
\hline 5 & 1,6 & 1,7 & 1,9 & 1,5 & 1,1 & 2,1 & 2,0 & 1,8 & 1,5 & 1,7 & 1,9 & 1,3 \\
\hline 6 & 2,1 & 1,7 & 1,5 & 1,9 & 1,5 & 1,4 & 1,6 & 1,7 & 2,0 & 1,9 & 1,6 & 1,8 \\
\hline 7 & 2,1 & 1,5 & 1,3 & 2,0 & 1,9 & 1,7 & 1,5 & 1,6 & 1,8 & 1,9 & 1,7 & 1,6 \\
\hline 8 & 1,2 & 1,8 & 2,1 & 1,9 & 1,6 & 1,8 & 1,5 & 2,1 & 1,9 & 2,0 & 1,1 & 1,4 \\
\hline 9 & 1,5 & 1,3 & 1,1 & 2,1 & 1,5 & 1,9 & 1,5 & 1,3 & 1,2 & 2,1 & 1,7 & 1,6 \\
\hline 10 & 1,6 & 1,8 & 1,9 & 1,1 & 1,2 & 1,6 & 1,9 & 2,1 & 1,9 & 2,0 & 1,8 & 1,1 \\
\hline 11 & 1,4 & 1,6 & 1,7 & 2,0 & 1,5 & 1,7 & 1,9 & 1,3 & 1,6 & 1,7 & 1,9 & 1,5 \\
\hline 12 & 1,9 & 1,6 & 1,7 & 1,5 & 1,8 & 1,5 & 1,3 & 2,0 & 1,2 & 2,1 & 1,8 & 1,2 \\
\hline 13 & 1,7 & 1,9 & 1,8 & 1,6 & 2,0 & 1,3 & 1,5 & 2,1 & 1,6 & 1,7 & 1,9 & 2,0 \\
\hline 14 & 1,9 & 1,3 & 1,2 & 1,7 & 2,1 & 1,9 & 2,0 & 1,1 & 1,9 & 1,2 & 1,8 & 2,1 \\
\hline 15 & 1,7 & 1,9 & 1,3 & 1,6 & 2,0 & 1,1 & 1,1 & 1,6 & 1,8 & 1,9 & 1,1 & 1,5 \\
\hline 16 & 1,6 & 1,7 & 2,0 & 1,8 & 1,7 & 1,9 & 1,3 & 1,6 & 1,7 & 1,9 & 1,5 & 1,4 \\
\hline 17 & 2,1 & 1,5 & 1,3 & 2,0 & 2,0 & 1,9 & 1,6 & 1,8 & 2,1 & 1,7 & 1,5 & 1,9 \\
\hline 18 & 1,5 & 1,2 & 1,5 & 1,8 & 1,8 & 1,9 & 1,7 & 1,5 & 1,1 & 1,5 & 1,9 & 1,6 \\
\hline 19 & 2,1 & 1,1 & 2,0 & 1,5 & 2,1 & 1,7 & 1,6 & 1,8 & 1,5 & 1,9 & 2,0 & 1,9 \\
\hline 20 & 1,1 & 2,1 & 1,9 & 2,0 & 1,6 & 1,7 & 1,6 & 1,8 & 2,0 & 1,8 & 1,5 & 2,0 \\
\hline 21 & 1,1 & 1,5 & 1,2 & 2,0 & 1,6 & 1,7 & 1,8 & 1,3 & 1,2 & 1,8 & 1,4 & 1,6 \\
\hline 22 & 2,0 & 1,5 & 1,9 & 1,5 & 1,8 & 2,0 & 2,1 & 1,7 & 1,8 & 2,1 & 1,6 & 1,8 \\
\hline 23 & 1,7 & 1,5 & 2,0 & 1,3 & 1,9 & 2,0 & 1,2 & 2,1 & 1,8 & 1,2 & 1,9 & 1,6 \\
\hline 24 & 1,9 & 2,0 & 1,3 & 1,5 & 2,0 & 1,8 & 1,1 & 1,6 & 1,8 & 1,9 & 1,5 & 1,6 \\
\hline 25 & 1,3 & 1,5 & 2,0 & 1,9 & 1,7 & 1,6 & 1,8 & 2,0 & 1,8 & 1,5 & 2,0 & 1,5 \\
\hline 26 & 1,7 & 2,0 & 1,8 & 1,5 & 1,9 & 1,3 & 1,6 & 1,7 & 1,9 & 1,5 & 1,4 & 1,6 \\
\hline 27 & 1,3 & 1,9 & 2,1 & 1,8 & 1,9 & 2,0 & 1,7 & 1,9 & 1,8 & 1,6 & 1,7 & 1,2 \\
\hline 28 & 1,9 & 2,0 & 1,8 & 1,7 & 1,5 & 2,0 & 1,2 & 1,8 & 1,9 & 1,5 & 1,7 & 1,6 \\
\hline 29 & 2,0 & 1,3 & 1,5 & 1,9 & 1,8 & 1,1 & 1,6 & 1,8 & 1,9 & 1,5 & 1,6 & 1,9 \\
\hline 30 & 1,9 & 2,0 & 1,8 & 1,7 & 2,1 & 1,6 & 1,8 & 1,5 & 1,8 & 2,0 & 1,1 & 2,1 \\
\hline 31 & 1,6 & 1,7 & 1,5 & 2,1 & 1,8 & 1,5 & 2,0 & 1,1 & 2,1 & 1,1 & 2,0 & 1,5 \\
\hline
\end{tabular}

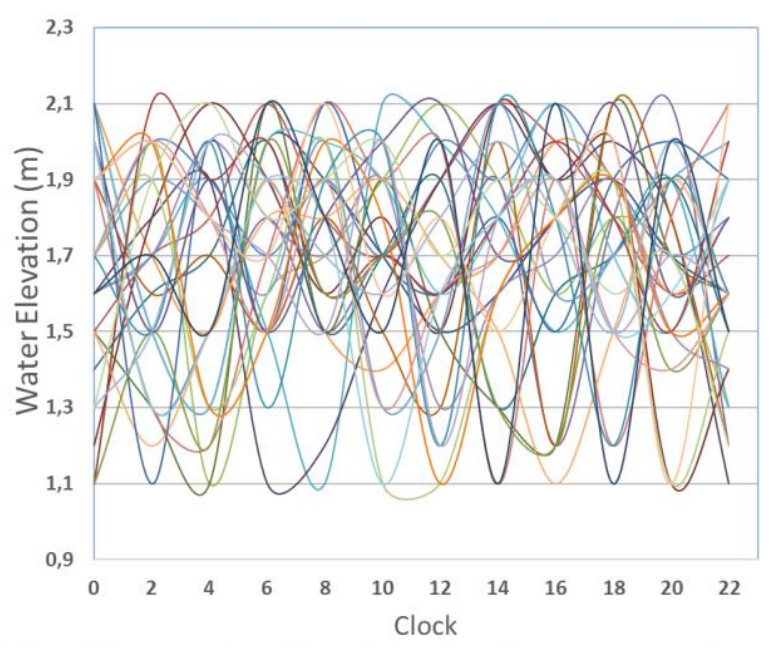

$-1-2-3-4-5-6-7-8-9-10-11$ $-12-13-14-15-16-17-18-19-20-21-22$ $-23-24-25-26-27-28-29-30-31$

Fig 7. Water elevation graph for water reservoirs in December 2014

With a total rainfall for 72 hours in December is often the case, the water reached its highest point but does not cause stagnant water Dewa Ruci underpass for a flood protection system that works well. The average elevation of water varies for different rainfall intensity. This shows that a flood safety system is needed which always works well to protect 
Dewa Ruci's underpass goal, which is to overcome congestion.

The water pump operates automatically with PLC control and water level control sensor. If the electrode is high level and low level of water submerged it will operate the pump. At one time two pumps operate simultaneously to dump water in a reservoir. In March 2014, it was raining continuously for 16 hours. Rain occurred on March 19 from 22.00 till 14.00 on March 20, with the length of the rain that occurred then pump operating hours also higher. Pumps performance can be seen in Figure 8 and Figure 9.

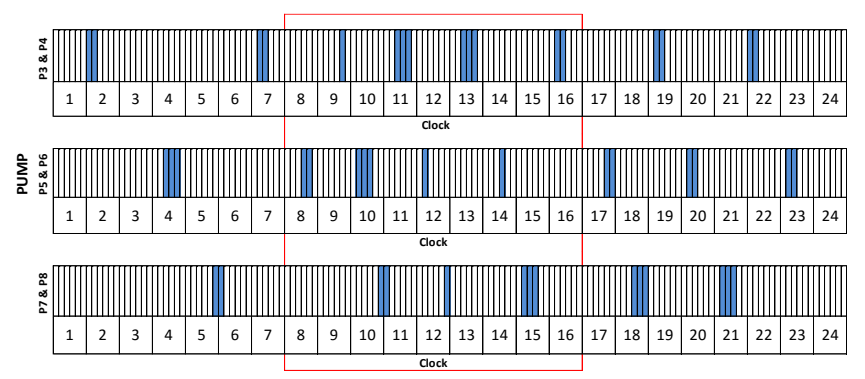

Fig 8. Graph Timer Pump Performance on March 20, 2014



Fig 9. Graph Timer Pump Performance on March 19, 2014

TABLE III

RAINY DAY IN MARCH 2014

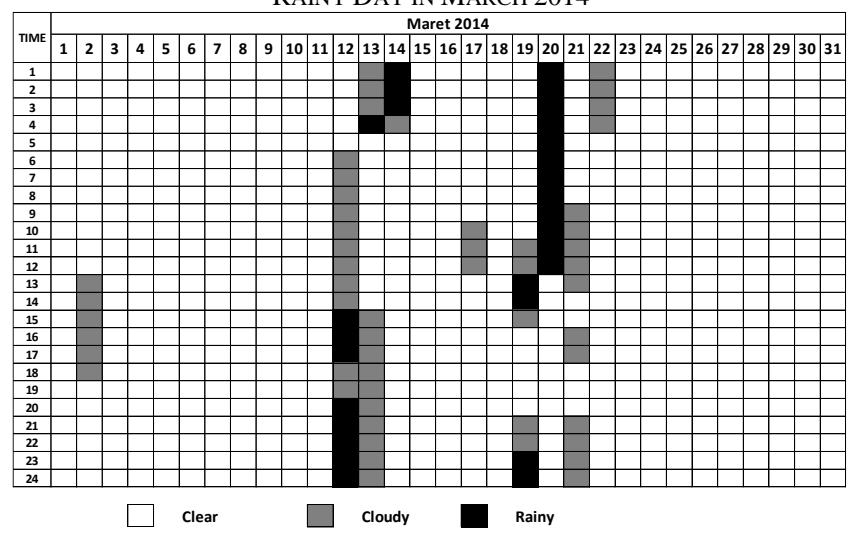

Interval operation of the pump from 08.00 to 17.00 is very tight due to the rain intensity is so high that the performance of the pump more often. Compared with the previous day's low rainfall so that the density interval pump operation becomes sparse.

Dewa Ruci intersection is managed by $P P K$ Simpang Dewa Ruci headed directly by Kepala SATKER PJN Metropolitan Denpasar. PPK Simpang Dewa Ruci has a subordinate (1) Pelaksana Admin authorized in administrative matters assisted by Pengurus Admin Umum and Penata Keuangan (2) Kepala Pelaksana Swakelola authorities in the operation and maintenance assisted by Pelaksana Pemeliharaan. (3) Koordinator Pengawas Lapangan authorized to conduct operations supervision is assisted by Pengawas Lapangan. (4) Penilik Jalan assigned to conduct observations on the use and condition of the road.

In performing its duty to maintain the operation of the Dewa Ruci underpass then as input for designing the organizational structure PPK Simpang Dewa Ruci. The organizational structure has been created to be a reference in this design and adding positions and responsibilities that is the operator. The operator is responsible for Pelaksana Pemeliharaan and Pengawas Lapangan to provide performance reports and observations.

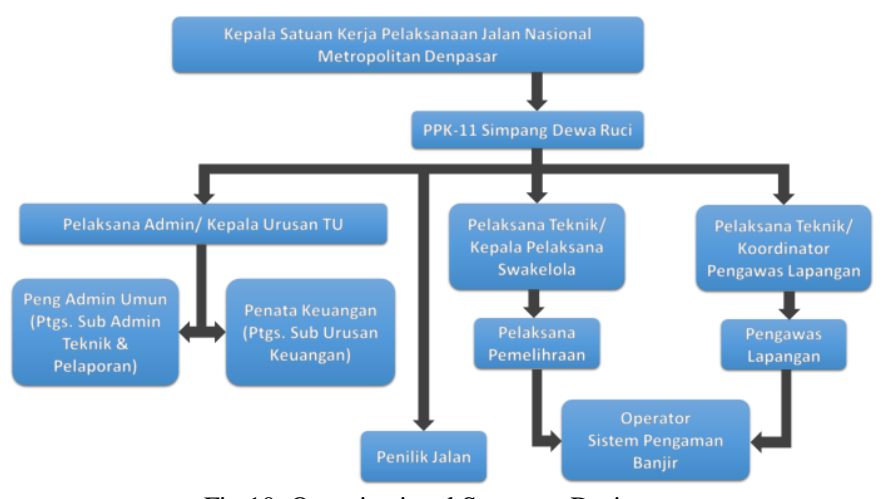

Fig 10. Organizational Structure Design

Standard operating procedure throughout the Dewa Ruci underpass carried out by operators working in the control room. The operator is responsible for Pelaksana Pemelihaan and Pengawas Lapangan's duty to provide a report of all standard operating procedures was undertaken. All reports will aim to evaluate the performance of operators and flood protection systems that will be refined in the future.



Fig 11. Design Flow Chart Standard Operating Procedure

Design a standard operating procedure that starts from the operator came on time according to the schedule has been adjusted. After arriving in the control room, the operator is 
obliged to clean the control room. Inspection begins with a look at the notes left by the previous operator to immediately done. A flood safety system that has been operating is automatically inspected and recording at a pump operating and the weather on the form provided. Before leaving the room, the operator gives a note to the next operator if there is work to be done.

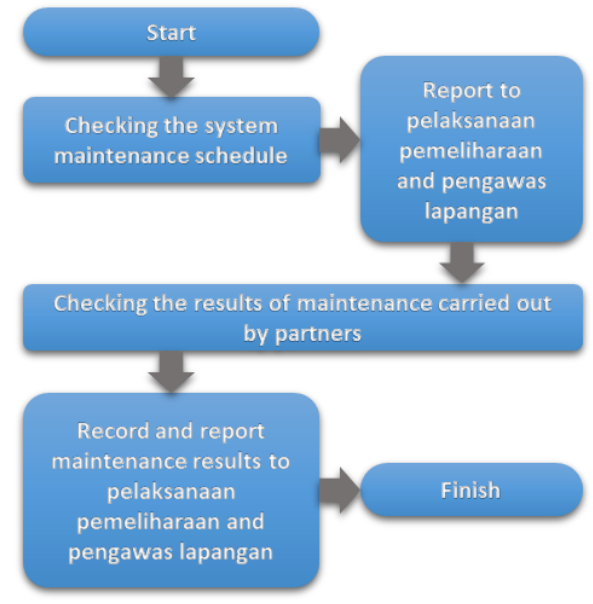

Fig 12. Flow Chart Design Standard Operating Procedure Flood Protection System Maintenance

Design a standard operating procedure flood safety system maintenance inspection maintenance schedule starts of each piece of equipment in the system. During maintenance work partners, operators in charge of examining the results of maintenance to be recorded and reported back to Pelaksana Pemelihara and Pengawas Lapangan.

The design of the standard operating procedure begins with the operation of the pump failure check the entire system if the faulty operation occurs to ensure the pump failure. After the pump is not connected to the system if it is still connected, stop the operation of the pump with a manual switch. Operate spare pump to replace the pump operation has failed and made sure the backup pump runs well and can help the system in operation. Report pump operation failure to Pelaksana Pemelihara and Pengawas Lapangan so knowing the problems that occur and immediately appoint business partners to make improvements. During the working partners do repairs, operators in charge of examining the result of improvements to be recorded and reported back to Pelaksana Pemelihara and Pengawas Lapangan.

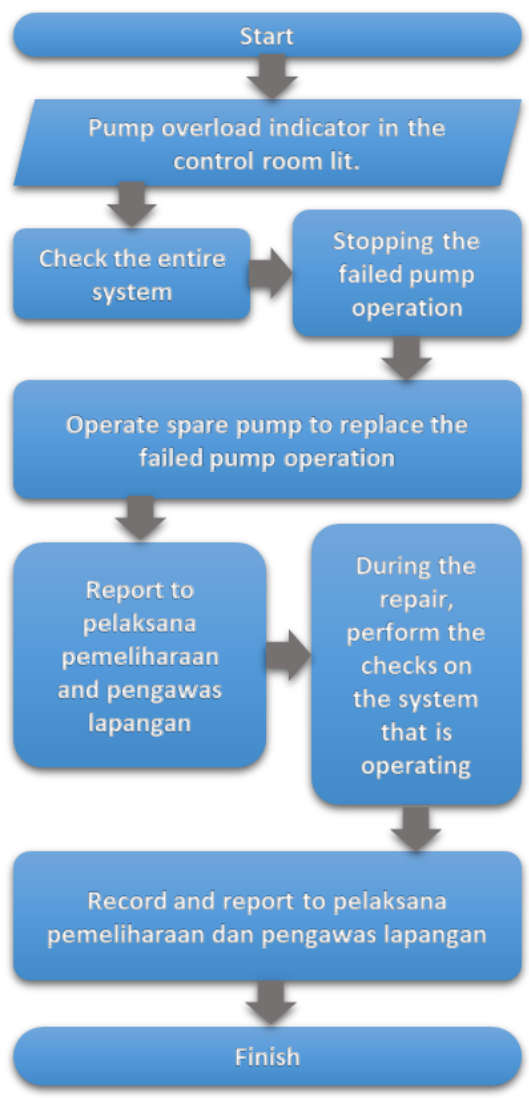

Fig 13. Flow Chart Design Standard Operating Procedure Operation Pump Failure

The state company that supplies electricity to the Dewa Ruci underpass is PLN. Dewa Ruci underpass built to address congestion, the PLN provide excellent service. But not forever PLN to supply electric power, the electric power distribution operations PLN periodic blackouts to perform network maintenance and unexpected conditions also occur in the electricity network as a disturbance.

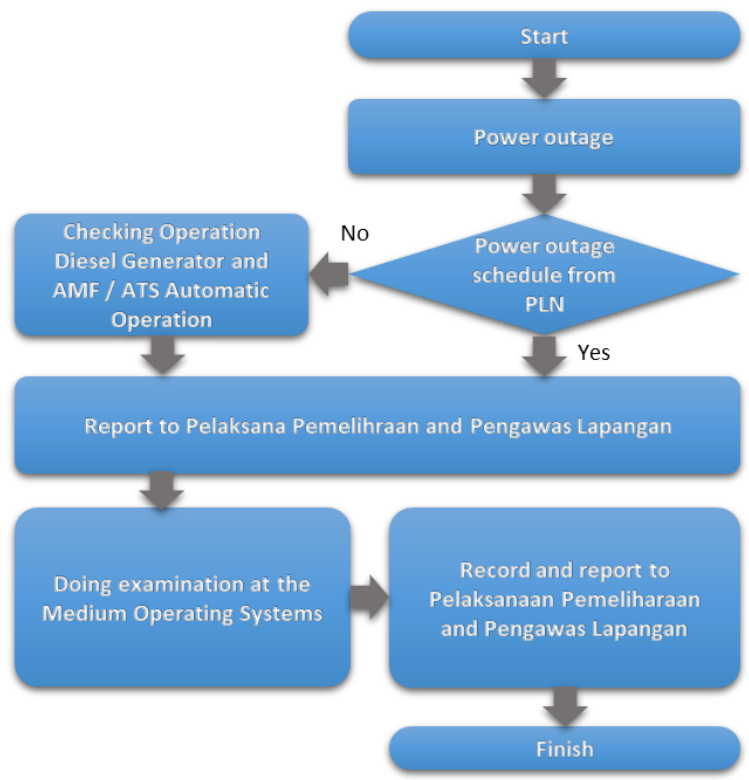

Fig 14. Flow Chart Design Standard Operating Procedure Power Outages 
PLN before will give you a report if power outage, then the operator will report a power outage to Pelaksana Pemelihara and Pengawas Lapangan. If a power outage due to interference and previously unannounced PLN, then the operator must check the operation of the diesel generator that operates automatically and ensure the system AMF / ATS as a substitute for the power supply switch works well. Record and report to Pelaksana Pemelihara and Pengawas Lapangan so that coordination with the PLN.

\section{CONCLUSION}

In this research has been carried out a study of the flood protection system Dewa Ruci underpass which produces standard operating procedure recommendations. To ensure the flood protection system work properly, models consisting of the management structure of an organization equipped with standard operating procedures are presented. Standard operating procedure for operators who maintain a flood protection system. The standard operating procedure is expected to support the operation and maintenance of the underpass flood protection system so it can function effectively and sustainably.

\section{REFERENCE}

[1] Assauri, S., 2004. Manajemen Produksi dan Operasi, Revisi. ed. FE UI.

[2] aws, ahy, 2015. BPKAD DKI: Rumah Pompa di Pluit Mati karena DKI Nunggak ke PLN. detiknews.
[3] Ayuningtyas, A., 2015. Inovasi Belanda dalam Teknologi Pencegahan Banjir dan Air Pasang.

[4] Barbera, L., Crespo, A., Viveros, P., Stegmaier, R., 2013. A Case Study of GAMM (Graphical Analysis for Maintenance Management) Applied to Water Pump in A Sewage Treatment Plant, Chile. Wiley Online Libr.

[5] Bijlsma, L., 2011. Water Management in the Netherlands.

[6] Davie, E., Hughes, P., 2010. Making The of Local Flood Management Planning in Melbourne's Municipalities and The Port Philip and Westernport Region.

[7] Heizer, J., Render, B., 2005. Operations Management, 7th ed. New Jersey.

[8] Horn, D., Granger, M., 2005. Optimizing The Asset Management of Pumps Through Integrated Online Monitoring, in PROCEEDINGS OF THE TWENTY-SECOND INTERNATIONAL PUMP USERS SYMPOSIUM.

[9] Max, T., 2013. Proyek Underpass Simpang Dewa Ruci. Proy. Underpass Simpang Dewa Ruci.

[10] Pieter, J., 2007. The Water System and Water Chain in Dutch Water and Environmental Legislation. LEAD J. Law Environ. Dev. J. 3/2, 202.

[11] PPK Simpang Dewa Ruci. 2014. Denpasar: Kementerian Pekerjaan Umum Direktorat Jenderal Bina Marga

[12] Satmoko, A., 2008. Analisis Kualitatif Teknik Thermography Infra Merah Dalam Rangka Pemeliharaan Secara Prediktif Pada Pompa. Pus. Teknol. Reakt. Dan Keselam. Nukl.-BATAN.

[13] Sunkpho, J., OOtamakorn, C., 2011. Real-time Flood Monitoring and Warning System. SJST Songklanakarin J. Sci. Technol., 233.

[14] Wahyu Hidayat, M., 2015. Cegah Banjir, Pemda Jakarta Siapkan 550 Pompa. Tempoco Metro.

[15] Woodward, M., Kapelan, Z., Gouldby, B., 2013. Adaptive Flood Risk Management Under Climate Change Uncertainty Using Rear Option and Optimisation. J. Risk Anal. 